\title{
The Degree of Graduates Suitability of the Faculty and Institutes of the Public Authority for Applied Education and Training for the Requirements of Labor Market in Kuwait from Employers Perspectives
}

\author{
Dr. Talal Ibrahim Almesad ${ }^{1,2}$ \\ ${ }^{1}$ Associate Professor, Ph.D. in Early Childhood Education and Psychological Counseling, University of Toledo, \\ USA \\ ${ }^{2}$ Department of Educational Assets and Administration, Faculty of Basic Education, The Public Authority for \\ Applied Education and Training (PAAET), Kuwait \\ Correspondence: Dr. Talal Ibrahim Almesad, Department of Educational Assets and Administration, Faculty of \\ Basic Education, The Public Authority for Applied Education and Training (PAAET), Kuwait.
}

Received: April 29, 2021

doi:10.5430/ijhe.v10n6p122
Accepted: June 11, 2021

Online Published: June 18, 2021

URL: https://doi.org/10.5430/ijhe.v10n6p122

\begin{abstract}
The current study aimed at determining the suitability level for the faculties and institutes graduates of the Public Authority for Applied Education and Training and the requirements of the labor market in the State of Kuwait from the employers' perspective in the public and private sectors. The study sample consisted of (2018) employers. A questionnaire was used after verifying its validity and stability. It was applied to an exploratory sample from the study population which are not included in the basic study sample. The results of the study showed that the suitability level of graduates of the Faculties and Institutes of the Public Authority for Applied Education and Training and the requirements of the labor market in the country Kuwait was moderate. The findings also revealed that there are statistically significant differences between the arithmetic means of the suitability level for graduates of faculty and institutes of the Public Authority for Applied Education and Training in favour of female employers, and differences were found according to the employer's graduation organization in favour of the Authority's graduates. Besides, the differences were found in both work sector in favor of the public work sector.
\end{abstract}

Keywords: Faculty and Institutes of the Public Authority for Applied Education, labor market requirements

\section{Introduction}

Education represents a basic source in countries' efforts to increase economic rates and human development. It also can reduce the level of unemployment, eliminate crime and poverty, and provide a decent life for its people. There is a direct relationship between the state's economic growth rate and the high educational level of individuals. Education and the development of human resources are closely related to the requirements. The advancement in human resources means the expansion of the economy, education, health, and state services. That is why, at the beginning of the third millennium, the Gulf states sought to lay down comprehensive economic development and societal reform plans. Their foremost priorities are the development of teaching and the provision of essential services to society in advancing the infrastructure.

The connection between the outputs of university education and the needs of the labor market indicates that education is in agreement with the requirements of the changing. Hence, the strengthening of the education objectives and maximizing its ability to withstand the change taking place in this market and predict it before its occurrence. This could be achieved by providing appropriate training facilities to its requirements, and increase awareness in the business sector and its institutions about the importance of the well-being of the humans where the society is the basis for the economic activity and not just for material profit (Qandili, 2007, and Nursi, 2012).

University education faces great challenges, including the increasing number of students and the number of graduates, certifications culture/value, the quality of more first-rate education, the frequency and overlapping of disciplines in universities with different names but the same content. This in return would weaken the creation of an integrated strategic program and alternation regarding the specializations and the flexibility of correlation between educational outputs and the dynamic needs of the labor market. In addition, closing in on the requirements of the 
local market without taking into account the potential upcoming developments of the market such as having foreign universities into the Arab market which implement unconventional educational teaching systems. Besides, an increasing tendency towards academic education, rather than technical, despite the growing marketplace need for technical manpower. Leading to an increase in the number of unemployed and their migration to work abroad due to studying unwanted specializations. In this fashion, dealing with the academic outcomes and the labor market gap must be managed by someone who experiences the following aspects:

First: Lack of sufficient confidence in the labor market components in the abilities and potentials of national academic institutions. Second: the absence of a complete and integrated employment strategy. Third: the rapid change in the needs of the labor market. Fourth: the lack of data present by the market and its reflection of the education institutions in response to the requirements of the market (Goldberg and Smith, 2007).

The financial reformation of the economy could be in terms of stimulating job vacancies in the private sector, encouraging small and medium enterprises, providing facilities and supporting these projects. Another key point is the intellectual development of academic education and its excellent quality by upgrading the academic skills of outstanding graduates by abundantly supplying extensive training to meet the needs and specific requirements of the local labor market. This would undoubtedly result in efficiently creating an advanced system for vocational guidance and academic counseling, traditionally starting from the program of the primary school stage. It could be performed through intensive improvement in teaching methods and curricula for all academic levels. Consequently, all these changes can contribute to the elimination of unemployment and help in obtaining flexible coordination between the outputs of more superior education and the labor market. Specific strategies must be applied to support the association between educational productions and market needs, the development of complex specializations, and the adoption of self-employment policy rather than employment. The mutual support for partnerships amidst the public and private sectors would enhance access to vocational education specialties such as renewable energy, hybrid power, surveying, and other modern disciplines and the development of the leadership and financing concepts for economic opportunities for small and medium enterprises (Kelly \& Bridges, 2005).

Adopting competitiveness among job applicants as a standard criterion of proficiency in the public and private sectors would contribute on one hand the appropriate person reaching the right place and on the other hand avoiding duplication in majors. It is significant to bear in mind the possibility of freezing some admission to specific majors as there is no demand for their graduates. It can therefore be assumed that expanding e-learning and distance learning courses, and rehabilitating study plans will undoubtedly help in keeping pace with the requirements of the current situations and the labor market. Concentrating on pure applied technical disciplines rather than academically, establishing operating units and following up on graduates, focusing on delicate modern skills, on the role of preparatory programs for choosing appropriate university majors will improve the quality of employees (Mahasneh, 2015).

In the State of Kuwait, approximately 25 thousand students graduate yearly from universities, faculties, and higher education institutions to get ready to enter the labor markets. Kuwaitis constitute approximately $(77 \%)$ of jobs in the government sector, while this percentage does not exceed $(5 \%)$ in the private sector. Therefore, higher education institutions decided to develop and train graduates, to achieve a connection between the local graduates and the requirements of the labor market. In order for the private and local sector to ultimately benefit from the graduate students, and for the government to succeed in implementing the Kuwaitization policy which is in the private sector's job vacancies are chiefly for Kuwaiti graduates instead of foreign and Arab employees. In fact, graduates encounter difficulties in joining the labor market (Al-Amro, 2010). The Public Authority for Applied Education and Training represents the most comprehensive academic institution in Kuwait before Kuwait University, where yearly ten thousand students graduate from it. The number of graduates statistically from the Public Authority for Applied Education and Training was (9356) graduates, while Kuwait University produces $(6,490)$ graduates in $2015 / 2016$.

The Public Authority for Applied Education and Training was established in December 1982, for the purpose of providing and developing the local workforce. Its aim is to ensure facing the shortcomings in the local technical workforce and meeting the country's development needs. The Authority is composed of the applied education, research, and the training sector. In addition, it contains a number of sectors that regulate the workflow, the planning and advancing sector, which is based on preparing the Authority's short and long-term development plans and programs to achieve the vision of His Highness the State of Kuwait Prince. The Kuwaiti plan of (2035) is to achieve human and economic expansion, building people and enhancing their capabilities. To meet the necessities of the 
labor market in various specialized fields. Among the relevant departments and centers in the planning and development sector are:

1) Graduate Studies and Labor Market Follow-up Department.

2) The Program and Curriculum Development Center.

3) The Decision Support Center.

4) Planning and Follow-up Department.

\subsection{Graduate Studies and Labor Market Follow-up Department}

It is one of the departments of the Planning and Development Sector in the Public Authority for Applied Education and Training. Its utmost aim is to know the supply and demand balance related to the Authority's outputs. Accordingly, they can achieve compatibility between outputs and the needs of the labor market and provide the local labor market in its government and private sectors with the required technical and specialized manpower from the Authority's outputs. This department represents the link between the Authority and its concern with employment in the state, such as the Civil Service Bureau, the State's Manpower Authority, banks, and the oil sector, to create and provide job opportunities for Kuwaiti youth after graduation. It uses official correspondings, face-to-face meetings, job opportunities exhibitions, telephone and electronic communication with the labor market to identify its future needs, and also conducts surveys to find out the opinion of graduates and employers about the graduates' competence and their willingness to work (Public Authority for Applied Education and Training website, 2020).

\subsection{Curriculum and Program Development Center}

Since 1998, the Curriculum and Program Development Center has been working on examining the needs of the Kuwaiti labor market and providing it with the professionally and technically prepared graduates proficiencies with the necessary skills and knowledge. To achieve this, they cooperate with faculties and institutes in the government and private sectors to realize the required specializations and skills. After all, they would prepare appropriate programs and curricula and follow up the development programs of the Authority's in comparison to the global evolution. The center also coordinates with faculties and modern institutes programs and curricula for their advancement where recently a competency program was introduced to cooperate in extending all faculty programs (Public Authority for Applied Education and Training website, 2020).

\subsection{Decision Support Center}

It is considered one of the Public Authority for Applied Education and Training centers, which main tasks are to support the decision-maker in education matters and training in accordance with the Kuwait Vision of (2035), and in agreement with the objectives of the country's progress plan by monitoring the reality and analyzing the current situation through the internal and external influences of the Public Authority. The applied education and training is to identify the essential problems and subsequently develop proposals for solutions to address those problems (Public Authority for Applied Education and Training website, 2020).

\subsection{Planning and Follow-up Department}

It is concerned with developing a vision and strategy originating from the vision of His Highness the Prince of Kuwait. This is in accordance with the framework of the country's development plan and with the participation of all sectors of the related authority, in order to accomplish the goals by following specific policies within determined time periods while identifying strengths and weaknesses in implementing these plans and programs. Besides, evaluating the level of performance by supervising the process of their Implementation and following them up through specific mechanisms and procedures (Public Authority forApplied Education and Training website, 2020).

\section{Previous Studies}

The Public Authority for Applied Education and Training in Kuwait team conducted a study between 1996-2000 on (4435) graduates as a representative of all faculties and institutes of the authority which was $(26,894)$ graduates. It was around $(16 \%)$ of the total graduates' number during the mentioned period.

While the sample of employers consisted of (604) officials from various employers the General Organization for Social Security and the Public Authority for Civil Information were contacted to determine the graduate work sites. The study revealed that $(74.5 \%)$ of the total sample work in the government sector, while (15\%) work in defense and security, $(3.1 \%)$ work in the oil sector, $(1.1 \%)$ work in the joint sector, $(1.7 \%)$ work in the private sector and $(0.3 \%)$ are retired, whereas $(4.3 \%)$ represent the unavailable data. The outcomes of the study showed that job satisfaction scored a $(79.68 \%$,) the desire to choose a major recorded $(78.90 \%)$, the general competency of the graduate is 
(77.44\%), the work relevant to the specialization is $(75.13 \%)$, the graduates' need for in-service training is $(69.2 \%)$, the adequate preparation for the job requirements programs $(65.63 \%)$, the willingness to work in the private sector $(42.2 \%)$.

Kuwait University carried out a study (2010) aimed at evaluating the labor market and its trends through the reality of quantitative and qualitative appointments of Kuwait University. They wanted to detect the outputs and their analyzes, determining the level of alignment of the university's outputs with the requirements ofthe labor market. Another goal was examining the time rate for employments and their implications for determining the quantitative and qualitative requirements of the university's outputs as well as predicting the requirements of the Kuwaiti labor market and expected job opportunities. The study employed the quantitative method in the analysis to study all the faculties and concluded with significant statistical indicators between (2007-2011), including the existence of a surplus in the expected faculties of Arts graduates for the labor market, especially in the field of history and philosophy and the Faculty of Social Sciences especially in the geography and political science majors. The university's production covers only about half of the market's need for professional specializations at (51\%), and the lowest in scientific faculties at (32\%) of the actual labor market needs for the years (2012-2016) (Kuwait University, 2013).

Al-Awadi (2005) study showed that the most primary manifestations of educational waste in Kuwait were: quantitative waste represented by students' failure and dropping out at numerous stages of education during school days, and qualitative waste represented in graduating students with an elementary academic level which they are not supposed to be this level. It is important to achieve harmonization between the outputs of applied education and training and the needs of the labor market in Kuwait. The state must work to restore balance in the labor market, improve the distribution of national elements among the sectors of government and private activity, and encourage them to engage in competent and productive work.

Mohammad, et al study's (2020) aimed to identify the philosophical dimensions of the job competencies of female humanities graduates in light of the goals of university education, the requirements of the twenty-first century, and the demands of the labor market at Faisal University in the Kingdom of Saudi Arabia. The researcher properly employed descriptive and analytical methods. The study sample consisted of (250) female graduates who answered a developed questionnaire prepared to achieve the research objectives. Through the direct results, it was pinpointed that the skills most in-demand in the twenty-first century gain behavioral, executive, and technological expertise, while social skills (writing, effective communication), functional (following up on job developments), administrative (time management, strategic planning), technical (device management) and academic (critical and creative thinking) with moderate degrees. Social skills (interviewing, seminar management), professional (social initiative), administrative (crisis management, project management, committee management and specific assignment of complex tasks, successful negotiation, official delegation, and considerable persuasion, leading academic (foreign language), and technological (digital in learning and intellectual development) in the last rank. The researcher recommended the establishment of a career counseling and employment support center and strengthening the partnership between the government and the private sector to obtain the greatest ways to develop the competencies of university graduates to ensure that they attain the best job opportunities that achieve their career and future aspirations.

Islam, et al (2018) conducted a study in the Faculties of Education in Palestinian universities to positively identify the qualitative competence of the perspective of their graduates of educational managers and supervisors. A structured questionnaire was developed, it had (28) items distributed into three domains (personal, cognitive, and professional competence). The study sample consisted of (111) directors and educational supervisors working in academic departments in Gaza for the scholastic year (2017-2018). Palestinian university graduates naturally obtain a considerable degree of personal competence by $(72.34 \%)$, followed by knowledge capability by (69.63\%), and professional competence by (64.34\%). The study did not demonstrate any statistically significant differences according to the gender variables, the nature of the profession, and the years of experience.

A study by Al- Absi (2017) was performed in the Republic of Yemen entitled "A proposed creative vision to correlate the outputs of the Community Colleges with the qualifications of the labor market in light of its current situation in the Republic of Yemen". It aimed accurately to identify the reality of Community Colleges from the point of view of academic leaders, faculty members, employers, and graduates of these Faculties. The investigation was conducted on five Community Colleges (Sanaa, Aden, Seiyun, Abs, Yarim), and the study tool was applied to a sample of (858) participants. The findings showed a weakness in the partnership between Community Colleges and labor market institutions in terms of training students, faculty members, and curricula. The tangible results also 
indicated that community colleges require to adapt to the necessary requirements ofthe local labor market and are not keen to eagerly pursue their graduates after graduation.

Al-Qudah, et al (2016) performed a study aimed at positively identifying the degree of compatibility of Jordania $\mathrm{n}$ higher education outcomes with the need of the labor market from the point of view of local community instituti ons administrators in Jordan. The investigation was carefully conducted on (380) community administrators in th e year (2014/2015). The findings of the study illustrated that the members of the local community assessed the $n$ eed for the labor market as moderate. However, the study did not demonstrate statistically significant differenc es in the percentage of harmonization of the Jordanian higher education outputs with the need of the labor mark et according to the job type variable. Recommendations were done to have some proposals to improve the out puts of higher education in line with the needs of the labor market.

The study of Mugheer and Abdel Amir (2016) intended to evaluate positively the performance of graduates of science departments in the Faculties of Basic Education from the perspective of managers in accordance with comprehensive quality standards. The selected sample consisted of (14) administrators and managers in Babil Governorate, Iraq.

The study questionnaire included (128) essential items divided into four specific areas (academic and professional preparation, personal preparation, social preparation, cultural preparation). The results abundantly showed that the general estimate for the four fields was high as it scored (82\%), where the cultural preparation came first, followed by the personal preparation, then the social preparation, and finally the academic and professional preparation. The findings did not reveal any statistical significance for the gender variable.

Al-Dalu (2016) efficiently conducted a study aimed at developing aproposed strategy to properly align the desired outputs of higher education with the specific needs of the labor market in Gaza. The chosen sample consisted of the specialty of pharmacy graduate students at Al-Azhar University, and employers of pharmacies, warehouses, and drug factories in Gaza. The results indicated that the graduates acquired a range of Cognitive and practical skills to a reasonable degree, while there was an apparent decline in their acquisition of mental and essential life skills and scientific research. The study also described a noticeable gap between education at universities and the needs required in the labor market for pharmacy graduates.

Tuhami's study (2016) intended to identify the level of adaptation of the Faculty of Education outputs to the needs of schools in the governorate of Beni Suef. The researcher used the descriptive and analytical approach through a questionnaire distributed to the educational supervisors. The results of the investigation showed the graduates' poor quality of preparing academic research in solving the educational problems. There were no statistically significant differences regarding the variables of experience, educational stage, and specialization.

The study of Al-Mahdi et al. (2015) purpose was to detect the compatibility of the outputs of the Faculties of Education with the needs of the academic labor market in the Sultanate of Oman. The researchers used the descriptive, analytical approach and content analysis of published and unpublished statistics. They also conducted interviews with specialists from the Faculty of Education at Sultan Qaboos University and from human resources in the Ministry of Education. The findings indicated a clear deficit in some scientific disciplines compared to the number of studies in the faculty. The researchers clarified the importance of developing a joint plan requirement between the Ministry of Education and preparing teachers institutions and comprehend the ministry's needs for future teachers.

The study of Mahasneh and Al-Sa idah (2015) aimed to reveal the Jordanian occupational standards that should be added to the electric power curricula needed by the labor market from the perspective of employers. The two researchers interviewed (30) employers in the main occupational group (use electricity), and distributed questionnaires to (39) employers in (generation electricity), (22) questionnaires to transmission and distribution electricity employers, and (26) questionnaires to automobile electricity employers. The analysis highlighted that all the Jordanian occupational standards imposed by the Vocational Training Corporation must be added to the curricula of the family of electric power. In addition to standards related to the main general skills such as (honesty, accuracy, proficiency in the English language, work proficiency, working with a team spirit, bearing work pressures, use the computer.

Al-Sallal study (2013) sought to identify the identification of life skills necessary for the requirements of the labor market in public education in the Kingdom of Saudi Arabia and to identify the most important challenges facing female graduate teachers in light of the present changes. The study sample consisted of (150) educational supervisors. The A list of life skills is summarized in skills in citizenship, mental skills, job skills, social skills, technical skills. 
The results showed that these skills were available to the average graduate teacher, while they did not have some of the basic skills needed by the labor market.

The study of Al-Zhalmi et al. (2012) aimed to measure the quality of higher education outputs and identify their strengths and weaknesses. The study sample consisted of two categories, the first from within the university represented by the faculty members at the Middle Euphrates University, and the other from managers and officials of most labor market institutions from the Middle Euphrates. One of the most substantial results of the study is the sample's consensus that the traits of the graduates' qualitative level is low, and it was evident from the results that the universities covered by the study did not adopt a process of measuring and evaluating the satisfaction of community institutions with their performance on a regular basis. The managers and officials of the work institutions agreed that there was a clear decline in the quality of training programs devoted to community service as well as scientific advice.

Obaidat and Saadeh (2010) executed a study titled "Skills Available in Jordanian Higher Education Outcomes as Required in the Local Labor Market." The study attempted to measure the degree of acquiring life skills (social communication skills, technology skills, initiative and creativity, foreign languages) among students in public and private universities. The study tool was applied to (228) male and female students in the fourth year at Zarqa Private University and the Hashemite University in Jordan. The findings of the study clarified that the rate of acquiring life proficiencies is similar for students in both universities. It also displayed some fundamental differences in the level of skillacquisition according to he variables of gender and type of faculty (scientific, literary).

Pereira (2013) implemented a study in Portugal to find out the most important life competencies that help graduates perform their jobs better in the labor market. The descriptive and analytical method was used by applying a questionnaire to (173) graduates from diverse universities in Portugal. The outcomes displayed that universities didn't pay much attention to preparing graduates for some life skills such as problem-solving, decision-making, self-confidence, personal skills, and working under the pressures needed by the labor market. The researcher recommended the importance of structuring school curricula to face the changes and developments in the labor market.

A study on African-Americans undergraduates performed by Horn (2008) to detect the desired effects on labor market outcomes in the United States of America.

The study sample consisted of (213) African-American college graduates. The results illustrated the existence of a statistically significant moderate relationship between the background of the university graduate' human and socio-economic capital on the one hand and the labor market output on the other hand. It also indicated that graduation from certain universities may positively or negatively affected the graduate's salary after graduation.

Mason, et al (2006) conducted a study aimed at assessing the impact of numerous types of employment skills initiatives in higher education on the labor market performance in Britain. The study sample consisted of (60) academic employees and (34) academic administrators from eight British universities. The results exhibited that work experience has positive effects on the ability of graduates by finding job opportunities within a short period not exceeding (6) months at the graduate level.

\subsection{Commenting on Previous Studies}

Several academic studies have shown that graduates prefer the government sector over the private sector, especially in Gulf countries Public Authority for Applied Education and Training, 2003; Kuwait University, 2016; Azzam and Individuals, 2009; Amin, 2012; Ministry of Higher Education, Sultanate of Oman 2016, many employers have demonstrated clear drawbacks on the competency of graduates to engage in work after graduation (Ministry of Higher Education in the Sultanate of Oman 2016; Mahmoud Qadouri, 2004; Al-Zhalmi and others, 2012; Al-Triki and Nokrat， 2013; Al-Absi， 2017; Al-Sallal， 2013; Tohamy， 2016; Kuwait University， 2010, 2016; Al-Awadi,2005), various studies demonstrated the competence of graduates and their readiness for the labor market (Islam and others, 2018; Hamed Al-Qudah and others, 2016; Mugheer and Abdul-Amir, 2016; Al-Dalou, 2016; The Public Authority for Applied Education and Training, 2003).

\section{Problem of the Study}

The Public Authority for Applied Education and Training seeks to adequately prepare young cadres in several specializations to meet the needs of the labor market in the governmental and private sectors. Curricula and programs in faculties and institutes aim to achieve harmonization between the different specializations and the requirements of the labor market. The realized gap led to the existence of many negative outcomes, including the increase in the unemployment rate and the waste of national money of the state. 
Many employers and recruiters believe that higher education graduates lack the basic practical skills required by the labor market, and the reason for the existence of a gap between the outputs of higher education and the job requirements from the employers'perspective that the real work environment differs from the theoretical studies that the student receives while studying. Moreover, many employers also explain that higher education graduates in the Arab and Gulf countries lack English language skills in speaking and writing, absence of seriousness in commitment with the tasks and responsibilities of the work entrusted to them. Therefore, the essence of the study problem lies in identifying the suitability of the graduates of the General Authority a nation for applied education and training for the requirements of the labor market and the extent of their professional competence from the employers' perspective.

The first question: What is the suitability level of the Faculties and Institutes of the Public Authority for Applied Education graduates and Training and the requirements of the labor market in the State of Kuwait from the employers' perspective?

The second question: Are there statistically significant differences between the arithmetic means of the suitability level of the Faculties and Institutes of the Public Authority for Applied Education and Training graduates and the necessary requirements of the labor market in the State of Kuwait according to gender and sector?

\section{Purpose of the Study}

This study sought to achieve integration between educational and training institutions by unifying visions, specific objectives, and policies regarding the needs of the labor market in its public and private sectors in the State of Kuwait. This could be done by identifying the views of employers in the public and private sectors according to the Public Authority for Applied Education and Training. outputs and the extent of their willingness to work after graduation.

The study also aimed to evaluate graduates from the local officials' perspectives and their appropriateness for the labor market in both the public and private sectors, therefore helping to shape education policy in line with the requirements of the times and sustainable development.

\subsection{Significance of the Study}

This study is valuable because it achieves the ambitious goals of the sustainable development plan of Kuwait in 2035 as to take care of the youth, and provide job opportunities for graduates in the various governmental and private sectors. This came in line with the general objectives of the Public Authority for Applied Education and Training in caring for its graduates, and filling the labor market need of technicians, teachers, and technologists. The tangible results of this study will also help decision-makers who are responsible for developing programs and curricula in the authority to introduce the required specializations, develop them, or freeze them, and to propose modern programs and methods that are compatible with the future plans of the state.

\subsection{Terminology of Study}

The Labor Market: "The community that includes business owners or representatives of companies, individuals and job-seekers for old employees with experience or recent graduates" (Al-Talaa, 2005, p. 13). Guenadili precisely defined it as "the available job opportunities in the public and private sectors" (Qanadili, 2007, p. 726). Al-Otaibi defined it as "meeting the needs of the local government and private sectors of qualified cadres and employing them in accordance with their specializations and in line with the available job opportunities" (Al-Otaibi, 2010, p. 25).

Correlation between educational outputs and market needs: Providing the labor market with competent and capable graduates of self and continuous learning, possessing the knowledge, skills, and competencies that help them integrate into their work in the manner required by the labor market (Aisan, 2006).

\section{Study Procedures}

\subsection{Study Methodology}

The study used the descriptive survey method.

\subsection{Study Population and Sample}

The labor market in the State of Kuwait of governmental and private entities and institutions.

\subsection{Study Population}

The study population consists of all employers who hire students who graduated from the Authority's Faculties (Faculty of Health Sciences, Faculty of Basic Education, Faculty of Nursing, Faculty of Business Studies, Faculty of Technological Studies) and institutes and courses (Higher Institute of Communications and Navigation, Institute of 
Construction, Institute of Tourism and Beauty, Institute of Nursing, Higher Institute of Energy, Industrial Institute in Sabah Al-Salem, Industrial Institute in Shuwaikh, Institute of Secretarial and Office Management, particular training courses).

\subsection{The Study Sample}

The study sample consisted of (2018) local employers for the sites in which the authority's graduates from the period (2000-2015) work in the public and private sectors, and the study included a number of graduates of the Association's Faculties (Faculty of Health Sciences, Faculty of Basic Education, Faculty of Nursing, Faculty of Studies. Business, Faculty of Technological Studies) and institutes and courses (Higher Institute for Communications and Navigation, Construction Institute, Institute of Tourism and Beauty, Institute of Nursing, High Energy Institute, Industrial Institute in Sabah Al-Salem, Industrial Institute in Shuwaikh, Institute of Secretarial and Office Management, special training courses) in the General authority for applied education and training from the years (2000 to 2015) working in the private and government sectors. Most of the questionnaires were submitted and collected through direct communication with employers at their original work sites, and the researcher used social media "WhatsApp" to communicate with the broadest possible number of employers. The study tool was prepared by referring to previous theoretical literature and studies such as the study of Obaidat and Saada (2010), and the study of Al-Sallal (2013). The study tool consisted in its initial form of (45) items, Liberia (Pereira, 2013), and Likert's Five Scale grading was used in this questionnaire. The study tool consisted of (6) dimensions, which are: theoretical courses, practical courses, readiness to work, commitment to work ethics, work related to specialization, suitability of work environment.

\subsection{Validate Study Tool}

The validity of the study tool was verified by presenting it to a group of arbitrators from among the faculty members in Kuwaiti universities and some employers. The modifications were made in light of the notes that were provided, and the tool consisted in its final form of (40) items.

\subsubsection{Stability of the Study Tool}

The stability of the study tool was verified by applying it to an exploratory sample of the study population which is not included in the basic study sample consisting of (30) employers, and after two weeks it was were re-applied to them. The correlation coefficient between both applications and the stability in terms of the Cronbach's Alpha internal consistency equation, and Table 1 shows these values.

Table 1. The reliability of the repetition method and the internal consistency of the Cronbach's Alpha study tool were evaluated

\begin{tabular}{clcc}
\hline serial & \multicolumn{1}{c}{ Dimension } & $\begin{array}{c}\text { Stability by } \\
\text { repetition }\end{array}$ & $\begin{array}{c}\text { Stability with the internal } \\
\text { consistency method } \\
\text { (Cronbach's Alpha) }\end{array}$ \\
\hline $\mathbf{1}$ & Theoretical courses & 0.78 & 0.84 \\
$\mathbf{2}$ & Practical courses & 0.80 & 0.82 \\
$\mathbf{3}$ & Readiness to work & 0.81 & 0.79 \\
$\mathbf{4}$ & Commitment to work ethics & 0.84 & 0.80 \\
$\mathbf{5}$ & Work related to specialization & 0.81 & 0.86 \\
$\mathbf{6}$ & Suitable working environment & 0.79 & 0.83 \\
\hline
\end{tabular}

It is noted from the results of Table 1 that the stability values by the repetition method and the internal consistency of the Cronbach's Alpha method were all appropriate for the purposes of the present study.

\subsubsection{Correction of the Study Tool}

To asses the arithmetic means the following equation was used (Highest value in ranking - lowest value)

Number of classes $=(5-1) / 3=1.33$

Low $2.33-1$

average $3.67-2.33$

is high $5-3.68$ 


\section{Results and Discussion}

The first question: What is the degree of suitability for graduates of the Faculties and Institutes of the Public Authority for Applied Education and Training and the requirements of the labor market in the State of Kuwait from the employers' prespective?

To answer the study questions, arithmetic means and standard deviations were extracted for the suitability for graduates' level of the Faculties and Institutes of the Public Authority for Applied Education and Training and the requirements of the Kuwaiti labor market from the employers' perspective, and the table (2) shows this.

Table 2. Arithmetic means and standard deviations of the suitability for graduates' level of the faculty and Institutes from the employers' perspective

\begin{tabular}{clcccc}
\hline serial & \multicolumn{1}{c}{ Dimension } & $\begin{array}{c}\text { Average } \\
\text { arithmetic }\end{array}$ & $\begin{array}{c}\text { Standard } \\
\text { deviation }\end{array}$ & Item order & Degree \\
\hline $\mathbf{1}$ & Theoretical courses & 3.30 & 0.80 & 6 & moderate \\
$\mathbf{2}$ & Practical courses & 3.52 & 0.78 & 2 & moderate \\
$\mathbf{3}$ & Readiness to work & 3.56 & 0.94 & 1 & moderate \\
$\mathbf{4}$ & Commitment to work ethics & 3.39 & 0.94 & 4 & moderate \\
$\mathbf{5}$ & Work related to specialization & 3.52 & 1.06 & 2 & moderate \\
$\mathbf{6}$ & Suitable working environment & 3.34 & 1.00 & 5 & moderate \\
& Total Grade & 3.44 & 0.86 & & moderate \\
\hline
\end{tabular}

The results of Table 2 revealed that the suitability level for graduates of the Faculties and institutes of the Public Authority for Applied Education and Training and the requirements of the labor market in the State of Kuwait from the perspective of employers was moderate. The arithmetic means was (3.44) with a standard deviation (0.86), and the arithmetic means ranged between (3.30) And (3.56), all of them came in a moderate degree. This result was in agreement with the findings of Muhammad (2020) study, which elucidated the level of functional competency of the members of the study sample was moderate, and also agreed with the results of the study of Al-Qudah (2016), which showed that the assessment of members of the local community for the need of the labor market was moderate.

The second question: Are there statistically significant differences between the arithmetic averages of the degree of suitability for graduates of the Faculties and Institutes of the Public Authority for Applied Education and Training and the requirements of the labor market in the State of Kuwait according to gender and sector?

To answer this question, the Independent Samples T-Test was used to examine the differences between the opinions of male and female graduates in the dimensions of the scale, the results appear in Table 3 as follows:

First: Gender:

Table 3. Arithmetic means, standard deviations, and a "T" test to examine the significance of differences between arithmetic means of the suitability level for graduates of the Faculties and Institutes according to the difference between gender

\begin{tabular}{lcccccc}
\hline \multicolumn{1}{c}{ Dimension } & \multicolumn{2}{c}{ Male } & \multicolumn{2}{c}{ Female } & "T" & Indicator \\
& $\begin{array}{l}\text { Average } \\
\text { arithmetic }\end{array}$ & $\begin{array}{l}\text { Standard } \\
\text { deviation }\end{array}$ & $\begin{array}{l}\text { Average } \\
\text { arithmetic }\end{array}$ & $\begin{array}{l}\text { Standard } \\
\text { deviation }\end{array}$ & & \\
\hline Theoretical courses & 3.24 & 0.78 & 3.36 & 0.81 & 3.31 & 0.001 \\
Practical courses & 3.43 & 0.80 & 3.59 & 0.76 & 4.40 & 0.001 \\
Readiness to work & 3.44 & 0.94 & 3.66 & 0.93 & 5.20 & 0.001 \\
Commitment to work ethics & 3.25 & 0.95 & 3.51 & 0.91 & 6.17 & 0.001 \\
Work related to specialization & 3.42 & 1.04 & 3.60 & 1.06 & 3.70 & 0.001 \\
Suitable working environment & 3.24 & 0.97 & 3.43 & 1.01 & 4.27 & 0.001 \\
Total Grade & 3.24 & 0.86 & 3.64 & 0.89 & 4.12 & 0.001 \\
\hline
\end{tabular}

It could be noticed from (t) test in Table No. 3 indicates that there are statistically significant differences at the level of significance $(\alpha=0.05)$ in all the total score, as the value of " $\mathrm{t}$ " was (4.12) in favor of female employers. The "T" 
values were all statistically significant for all dimensions and in favor of female employers. It could be contributed to the seriousness and efficiency of females at work more than males. This is consistent with many studies that indicate the existence of differences, whether in achievement or aptitude for work in favor of females. The findings of this question were incompatible with the results of Islam et al, (2018) study, and the Tuhami study (2016), which all showed no differences attributable to the gender variable.

\section{Second: Graduation Source}

Table 4. Arithmetic means, standard deviations, and a "T" test to examine the significance of differences between arithmetic means for the suitability of graduates' level of the Faculties and Institute.

\begin{tabular}{lcccccc}
\hline \multicolumn{1}{c}{ Dimension } & \multicolumn{2}{c}{ Authority Graduates } & \multicolumn{2}{c}{$\begin{array}{c}\text { Graduates from other } \\
\text { regions }\end{array}$} & $\begin{array}{c}\text { "T" } \\
\text { value }\end{array}$ & Indicator \\
& $\begin{array}{l}\text { Average } \\
\text { arithmetic }\end{array}$ & $\begin{array}{c}\text { Standard } \\
\text { deviation }\end{array}$ & $\begin{array}{l}\text { Average } \\
\text { arithmetic }\end{array}$ & $\begin{array}{l}\text { Standard } \\
\text { deviation }\end{array}$ & & \\
\hline Theoretical courses & 3.32 & 0.79 & 3.30 & 0.81 & 0.61 & 0.538 \\
Practical courses & 3.58 & 0.78 & 3.49 & 0.78 & 2.27 & 0.021 \\
Readiness to work & 3.63 & 0.94 & 3.53 & 0.94 & 2.15 & 0.032 \\
Commitment to work ethics & 3.48 & 0.91 & 3.35 & 0.95 & 2.65 & 0.008 \\
Work related to specialization & 3.66 & 0.99 & 3.46 & 1.08 & 3.96 & 0.001 \\
Suitable working environment & 3.51 & 0.93 & 3.27 & 1.01 & 5.08 & 0.001 \\
Total Grade & 3.68 & 0.87 & 3.20 & 0.89 & 3.40 & 0.002 \\
\hline
\end{tabular}

Results of Table 4 revealed that the value of (T) is statistically significant at the level of significance $(\alpha=0.05)$ in the total grade, as the value of " $\mathrm{T}$ " reached (3.40) for the benefit of the Authority's graduates. The "T" values were all statistically significant for all dimensions, with the exception of the "Theoretical courses". The results also illustrated that there are statistically significant differences in the other dimensions in favor of the Authority's graduates. It may be attributed to the quality of education among the Authority's graduates and they have the necessary skills for the labor market compared to the graduates of other regions.

Third: The sector (governmental / private).

Table 5. Arithmetic means, standard deviations, and a "T" test to examine the significance of differences between arithmetic means of the degree of suitability for graduates of the Faculties and Institutes according to the different labor sector

\begin{tabular}{|c|c|c|c|c|c|c|}
\hline \multirow[t]{2}{*}{ Dimension } & \multicolumn{2}{|c|}{ Public Sector } & \multicolumn{2}{|c|}{ Private Sector } & \multirow{2}{*}{$\begin{array}{l}\text { "T" } \\
\text { value }\end{array}$} & \multirow[t]{2}{*}{ Indicator } \\
\hline & $\begin{array}{l}\text { Average } \\
\text { arithmetic }\end{array}$ & $\begin{array}{l}\text { Standard } \\
\text { deviation }\end{array}$ & $\begin{array}{l}\text { Average } \\
\text { arithmetic }\end{array}$ & $\begin{array}{l}\text { Standard } \\
\text { deviation }\end{array}$ & & \\
\hline Theoretical courses & 3.31 & 0.79 & 3.17 & 0.98 & 1.83 & 0.066 \\
\hline Practical courses & 3.54 & 0.76 & 3.22 & 1.09 & 4.26 & 0.001 \\
\hline Readiness to work & 3.57 & 0.92 & 3.33 & 1.21 & 2.71 & 0.007 \\
\hline Commitment to work ethics & 3.41 & 0.91 & 3.08 & 1.31 & 3.71 & 0.001 \\
\hline Work related to specialization & 3.55 & 1.01 & 2.97 & 1.52 & 5.84 & 0.001 \\
\hline Suitable working environment & 3.38 & 0.95 & 2.75 & 1.40 & 6.65 & 0.001 \\
\hline Total Grade & 3.60 & 0.76 & 3.28 & 0.98 & 4.67 & 0.002 \\
\hline
\end{tabular}

It is evident from the results of Table 5 that the value of $(\mathrm{T})$ is statistically significant at the level of $(\alpha=0.05)$ in the total grade. The " $\mathrm{T}$ " values were all statistically significant for all dimensions, except for the "Theoretical courses" dimension. The outcomes also indicated that there are statistically significant differences in the other dimensions and in favor of the public sector employers. This result may be attributed to the difference in the employment system in both the public and private sectors. Thus, it seems that the Authority's graduates are more appropriate to work in the government sector compared to the private sector. This result is relatively consistent with the results of the Aldalu study (2016), which revealed the clear gap between education in universities and the needs required in the labor market for pharmacy graduates. 


\section{Conclusion and Recommendations}

The outcomes demonstrated the urgent need to develop applied and higher education and training programs to be able to produce human resources that are compatible with the labor market, its requirements and the continuous changes due to the great gap between them.

The findings of the study explained the suitability level of graduates of the Faculties and Institutes of the Public Authority for Applied Education and Training and the requirements of the labor market in the country Kuwait was moderate. In addition, there were statistically significant differences between the arithmetic means of the suitability level for graduates in favour of female employers. The employer's graduation organization was in favour of the Authority's graduates. Finally, the outcomes eluminated the graduates desire to work at the public work sector more than the private one.

In light of the results obtained, the researcher recommends the following:

- Encouraging more field studies and research that explain the problems and phenomena of labor market issues, future professions and future prospects.

- Organizing periodic meetings for higher education and training institutions and proposing transparency with the private and governmental labor market to discuss the most important obstacles and to suggest ways to overcome them.

- Establishing vocational guidance and counseling centers in general education schools and providing tests and standards through which students can be directed to various labor market entities.

- Unifying the goals, policies and visions of public, higher education and professional academic institutions that relate to the market requirements according to the current expansion, technological advancement and the sustainable development plan of the State of Kuwait in coordination with the governmental and private labor market.

\section{References}

Aisan, Salha. (2006). The compatibility between higher education outcomes and development requirements, a paper presented to the regional workshop on education response to social development requirements, the Islamic Educational, Scientific and Cultural Organization (ISESCO), Muscat: Oman (17-18 December, 2006).

Al -Absi, Raheeb Saeed. (2017). A proposed scenario to harmonize the outputs of community colleges in the Republic of Yemen with the requirements of the labor market in light of its current reality. Arab Journal for Quality Assurance of University Education, 10(28), 155-181. https://doi.org/10.20428/AJQAHE.10.2.7

Al-Amro, Saleh Abdel-Rahman. (2010). Alignment between education and training outcomes and the needs of the labor market. The experience of the General Organization for Technical and Vocational Training in the Kingdom of Saudi Arabia. A working paper in the Arab Forum on technical and vocational training and the needs of the labor market (16-18 January 2010): Riyadh, Saudi Arabia.

Al-Awadi, Badria Abdullah. (2005). The Kuwaiti experience in achieving harmonization between the outputs of applied education and vocational training and the requirements of the labor market. A working paper submitted to the national symposium on the requirements of the Arab labor market in light of international changes, Cairo.

Aldalu, Hamdi. (2016). A proposed strategy to harmonize the outputs of higher education with the needs of the labor market in Palestine. (Master Thesis). Postgraduate Academy of Management and Politics. Palestine.

Al-Otaibi, Munir bin Mutni. (2010). The suitability of higher education outputs to the needs of the labor market, analytical studies. The Educational Journal, 24 (94).

Al-Qanadili, Jawaher bint Ahmed. (2009). Higher education for girls and its support for the labor market in the Kingdom of Saudi Arabia, the Arab Regional Conference - Towards an Arab space for higher education (current challenges and societal responsibilities). UNESCO Regional Office for Education in the Arab Countries - Beirut.

Al-Sallal, Mounira. (2013). The extent of the availability of life skills necessary for the labor market of a university graduate teacher from the point of view of the educational supervisors. College of Social Sciences, Imam Muhammad bin Saud Islamic University. Journal of the Humanities and Social Sciences, 31(59), 63-113. 
Al-Talaa, Ahmad. (2005). Availability of the elements of the National Commission for Accreditation, Quality and Quality in Higher Education Institutions in the Gaza Strip, an unpublished Master of Business Administration thesis. The Islamic University, Gaza: Palestine.

Amin, Hana (2012). Higher Education and Labor Market Requirements: The Experience of the Sultanate of Oman. Paper presented at the Fifth Conference of the Omani Economic Association, "Demographic Shifts and the Gulf Labor Market". Muscat 18/1/2012.

Association of higher Education Careers services. (2015). Ireland's leading graduate employers. Ireland. Retrieved from https://gradireland.com/irelands.

Azzam, Ahmed Zakaria and Al-Fardi Mahmoud Hussein. (2009). Assessment of banks by competence among graduates of private universities who work in them - a case study for a major in Banking Finance - Zarqa University.

Guenadili, Jawaher Ahmed. (2007). An evaluation study of the harmonization between the external competence of higher education for the girl and the requirements of the labor market in the Kingdom of Saudi Arabia. The Eighth Scientific Conference on Education (Quality and Accreditation of Higher Education Institutions), Arab Republic of Egypt, Volume 2, 719-856.

Goldberg, J., \& Smith, J. (2007). Effects of education on labor market outcomes. Higher Education Journal, Revision Edition, 8(3), 1-48.

Al-Qudah, H. Amin, M. Dagher, Khadir, A., \& Tarawneh, A. (2016). The degree of relevance of Jordanian education outcomes to the needs of the labor market. Educational Science Studies, 43(5), 2033-2049.

Horn, S. (2008). Influences on labor market outcomes of african american college graduates: a national study. Journal of Higher Education, 79(1), 27-28. https://doi.org/10.1080/00221546.2008.11772085

Islam, Nour Yahya. Al-Dajani, Iyad Ali \& Agha, Amira Bassam. (2018). Qualitative competence of graduates of Faculties of Education in Palestinian universities from the viewpoint of educational administrators and supervisors. The Arab Journal for Quality Assurance of University Education, 11(37), 51-74. https://doi.org/10.20428/AJQAHE.11.37.3

Junek, O., Lockstone, L., \& Mair, J. (2009). Two perspectives on event management employment: students and employer insights into the skills required to get the job done. Journal of Hospitality and Tourism Management, 16, 120-29. https://doi.org/10.1375/jhtm.16.1.120

Kelly, C., \& Bridges, C. (2005). Introducing professional and career development skills in the marketing curriculum. Journal of Marketing Education, 27(3), 212-218. https://doi.org/10.1177/0273475305279526

Kuwait University (2010). Study matching the outputs of Kuwait University with the needs of the Kuwaiti labor market. Office of the Vice Chancellor for Planning: Kuwait.

Kuwait University (2013). The expected quantitative development of the Bakarelius campaign between the needs of the labor market and the outputs of Kuwait University for the years 2012-2016. Office of the Vice Chancellor for Planning: Kuwait University.

Mahasneh, Omar Musa, Al-Sa idah \& Monem Abdel-Karim. (2015). Jordanian professional standards that should be added to the curricula of the family of electric power, which the labor market needs from the point of view of employers. Educational Sciences Studies, 42(1).

Mahdi, Yasser., Al-Busafi, Majid., \& Al Habisa, Lamia. (2015). Alignment between the outputs of the Faculties of Education and the needs of the educational labor market in the Sultanate of Oman. An analytical study. The Specialized Educational Journal, 4(7), 1-20.

Mason, G., Williams, G., \& Cranmer, S. (2006). Employability Skills Initiatives in Higher Education: What Effects Do They Have on Graduate Labour Market Outcomes? National Institute of Economics and Social Research, Institute of Education, University of London, September 2006.

Ministry of Higher Education (2016). Attitudes of employers in employing graduates in the private sector (a survey). Sultanate of Oman.

Mugheer, Abbas \& Abdel-Amir, Suhad. (2016). Evaluating the performance of graduates of science departments in the Faculties of Basic Education from the point of view of school administrations in accordance with 
comprehensive quality standards. University of Babylon. Ethnicity. Babylon University Journal of Human Sciences, 24(2), 829-860.

Nursi, Ronak Tawfiq Ali. (2012). Education outputs and labor market integration in Iraq. A working paper submitted to the Conference on Integration of Education Outcomes with the Labor Market in the Public and Private Sectors. Al-Balqa University: Jordan. March 25-29, 2012.

Obeidat, Osama. Happiness, prevalent (2010). The skills available in the Jordanian higher education outcomes, as required by the local labor market. The Arab Journal for Quality Assurance of University Education, University of Science and Technology, Yemen, 3(5), 74-95.

Pereira, O. (2013). Soft skills: from university to the work environment. Analysis of a survey of graduates in Portugal. Regional and Sectoral Economic Studies, 13(1), 105-118.

Public Authority for Applied Education and Training (2003). Study of evaluation and follow-up of graduates of the Faculties and Institutes of the Public Authority for Applied Education and Training in the Labor Market for the period (1996-2000): a field study.

The Chamber of Commerce and Industry in Riyadh (2005). A study of the reality and future of expatriate workers in the Kingdom of Saudi Arabia, Riyadh Economic Forum (4-6 December 2005).

Tuhami, Abdel-Gawad. (2016). The extent to which the outputs of the Faculty of Education, BeniSuef University are compatible with the needs of the labor market from the beneficiaries'point of view. Journal of Culture and Development in Egypt, 16(105), 326-377.

Zhalmi, Mohsen., Emirate, Ahmed., \& Al-Asadi, Abd Ali. (2012). Measuring the quality of higher education outcomes from the viewpoint of universities and some labor market institutions (an analytical study in the Middle Euphrates region). Journal of Management and Economics, 34 (90), 147-171.

\section{Copyrights}

Copyright for this article is retained by the author(s), with first publication rights granted to the journal.

This is an open-access article distributed under the terms and conditions of the Creative Commons Attribution license (http://creativecommons.org/licenses/by/4.0/). 